Research Paper

\title{
Evaluation of two recommended disinfection methods for cleaning cloths used in food services of southern Brazil
}

\author{
Sabrina Bartz, Eduardo Cesar Tondo \\ Instituto de Ciência e Tecnologia de Alimentos, Universidade Federal do Rio Grande do Sul, \\ Porto Alegre, RS, Brazil.
}

Submitted: March 16, 2012; Approved: November 13, 2012.

\begin{abstract}
In the State of Rio Grande do Sul (RS), Southern Brazil, a good manufacturing practices regulation was published recommending two disinfection methods for cleaning cloths used in food services. The aim of the present study was to evaluate the efficacy of those methods. Cleaning cloths were sampled without prior notice at food services, on common working days. For the analyses, the cloths were divided in two sub-samples, being one of them microbiologically analyzed. The second sub-sample was further divided in two pieces and submitted to hand washing for two minutes. After that, one piece was boiled in water for $15 \mathrm{~min}$ and the other one was soaked in a $200 \mathrm{ppm}$ sodium hypochlorite solution for $15 \mathrm{~min}$. Both pieces of cloth were submitted to microbiological analyses. Cleaning cloths presented total aerobic mean counts of $6.9 \pm 6.7 \mathrm{log} / \mathrm{cm}^{2}$. All cleaning cloths presented coliform contamination, and $40 \%$ demonstrated mean counts of $6.2 \pm 5.6 \mathrm{log} / \mathrm{cm}^{2}$. Presumptive S. aureus mean counts of $5.5 \pm 4.9 \mathrm{log} / \mathrm{cm}^{2}$ were found. No statistic correlation was observed among the number of meals served daily in the food services and the microbiological contamination levels. After washing and disinfection, microbiological counts were significantly $(\mathrm{p}<0.05)$ reduced by both methods, achieving an approximately $5 \log$ reduction. The reductions achieved by the sodium hypochlorite soaking method and the boiling method were not significantly different. Thus, it was possible to conclude that both recommended methods were suitable to disinfect cleaning cloths used in food services.
\end{abstract}

Key words: cleaning cloths, disinfection, The State of Rio Grande do Sul, Brazilian food services.

\section{Introduction}

The incidence of reported foodborne diseases has been increased worldwide (Norrung and Buncic, 2008; Sofos, 2008; Greig and Ravel, 2009;), including in Brazil (Oliveira et al., 2007). The magnitude of this problem is bigger than reported by official surveillance bodies because the majority of the foodborne outbreaks are not officially reported. As previously described (Arbuthnott,1990), less than $2 \%$ of the cases of foodborne acute gastroenteritis are detected by current surveillance/reporting process, and food services as bars, restaurants and hotels are among the most involved places where outbreaks have occurred. Many authors have indicated improper food preparation, inadequate storage or cooking and cross-contamination as the main cause of foodborne illnesses (Bean et al., 1996; Scott, 1997; Simone et al., 1997; Olsen et al., 2000; Walker, 2003a). Cleaning cloths have been identified as an important potential cause of cross-contamination, representing a significant source of biological hazards. When contaminated cleaning cloths are rubbed on surfaces, organisms are invariably transferred to the surfaces of equipment and hands of food handlers in sufficient numbers to cause food contamination (Scott and Bloomfield. 1990b). Furthermore, the presence of food leftovers and the high humidity that cleaning cloths usually present could easily promote microbial multiplication under room temperature. Confirming the microbiological risk that cleaning cloths may represent, different species and counts of microorgan-

Send correspondence to: E.C. Tondo. Instituto de Ciência e Tecnologia de Alimentos, Universidade Federal do Rio Grande do Sul, Campus do Vale, Agronomia, Porto Alegre, RS, Brazil. E-mail: tondo@ufrgs.br. 
isms have been found in cleaning cloths used in households and food services (De Wit et al., 1979; De Boer and Hahne, 1990; Cogan et al., 1999). Among the main factors that contribute to the frequent use of cleaning cloths in households and food services are the impossibility of moving heavy equipment for cleaning procedures, the presence of electric components which make it impossible to rinsing under running tap water, and also the lower cost of cotton cleaning cloths when compared to disposable cloths.

In order to reduce the microbiological contamination of cleaning cloths, a good manufacturing practices regulation (RIO GRANDE DO SUL, 2009) was published in 2009 by the Health Authority of the State of Rio Grande do Sul, Brazil. This regulation recommended two methods for disinfection of cleaning cloths in food services. It was the first Brazilian regulation to recommend the boiling of cloths in water for $15 \mathrm{~min}$ or their immersion in $200 \mathrm{ppm}$ of sodium hypochlorite solution for $15 \mathrm{~min}$, in order to disinfect the cleaning cloths. Even though both methodologies are well known and are assumed to be able to reduce microbiological counts of cleaning cloths, no scientific evaluation has been published so far or has been included in the aforementioned regulation.

Considering these aspects, the present study aimed to evaluate the efficacy of the two methods recommended by Portaria 78/2009 for disinfection of cleaning cloths used in food services.

\section{Materials and Methods}

\section{Sampling procedures}

Thirty five used cotton cleaning cloths were collected from the kitchen of 13 food services located in Porto Alegre city, Rio Grande do Sul. Among the food services, 10 were restaurants and three were industrial kitchens. The selection of the food services included in the study was based on the following criteria: to prepare at least 250 daily meals; to serve the food in buffet. In all the commercial food services at least the basic Good Manufacturing Practices (GMP) procedures were implemented, while in six of them GMP manual or GMP certification were provided. At the time of sampling, all the industrial kitchens had implemented GMP manual and Sanitarian Standard Operation Procedures (SSOP), and had a nutritionist engaged for the process control. One of the industrial kitchens prepared approximately 7,000 daily meals, while the other two prepared 750 and 320 daily meals, respectively. Prior to the sampling, the authorization of the food service's manager was requested. The samplings were conducted on different weekdays, without previous information of the food handlers. After being used for at least two hours in the kitchen, two cleaning cloths were collected in each commercial restaurant $(\mathrm{n}=26)$, and three in each industrial kitchen $(\mathrm{n}=9)$, totalizing 35 cleaning cloths samples. The collected samples were placed in sterile plastic bags and transported un- der refrigeration to the Food Microbiology Laboratory of Instituto de Ciência e Tecnologia de Alimentos ICTA/UFRGS.

\section{Preparation of cleaning cloths for analyses}

The cleaning cloths were measured and the size was standardized $(35 \mathrm{~cm} \mathrm{x} 70 \mathrm{~cm}$ ) using a disinfected scissor and gloved hands. After that, the cloths where divided into two sub-samples $(35 \times 17.5 \mathrm{~cm})$. On sub-sample was used to determine the initial number of bacteria in the cleaning cloth. The other sub-sample was further divided in two pieces of equal size $(17.5 \times 17.5 \mathrm{~cm})$, which were submitted to the two disinfection methods.

\section{Cloth contamination analyses}

The first sub-sample of each 35 cleaning cloths was suspended in $500 \mathrm{~mL}$ of $0.1 \%$ peptone water (Merck, Darmstadt, Germany), and agitated by hand, for $10 \mathrm{~min}$. An $1 \mathrm{~mL}$ - aliquot of the homogenate was added to $9 \mathrm{~mL}$ of $0.1 \%$ peptone water and successive decimal dilutions were carried out. Aliquots $(20 \mu \mathrm{L})$ of each dilution were plated, in duplicate, on Plate Count Agar (PCA, Merck, Darmstadt, Germany), Baird Parker egg yolk-tellurite Agar (BP, Merck, Darmstadt, Germany) and Violet Red Brilliant Agar (VRBA, Merck, Darmstadt, Germany) for enumeration of Total Aerobic Counts (TAC), presumptive Staphylococcus aureus (grey/black shiny colonies with or without lipase activity) and presumptive coliforms (red, surrounded by reddish precipitation zones with 1 to $2 \mathrm{~mm}$ colonies), respectively. Plates were incubated at $30{ }^{\circ} \mathrm{C}$, for $24-48 \mathrm{~h}$ and the colonies were counted. Presumptive $S$. aureus were confirmed by the coagulase test (FDA, 1992). Results were expressed as $\log \pm \mathrm{SD} \mathrm{cfu} / \mathrm{cm}^{2}$ of cloth.

\section{Evaluation of disinfection methods}

The second sub-sample was divided in two equal pieces ( 70 units of $17.5 \times 17.5 \mathrm{~cm}$ ) and submitted to the two disinfection methods recommended by Portaria 78/2009 (RIO GRANDE DO SUL, 2009). All cloth samples ( $\mathrm{n}=70)$ were hand washed for approximately two minutes, by a same person, using potable water $(0.2 \%$ residual chlorine $)$ and $2 \mathrm{~mL}$ of a commercial neutral detergent (Trademark Minuano, Brazil) purchased from a retail supermarket. Microbiological counts were measured after hand washing in three cleaning cloths in order to check if this step contributes significantly with the microbiological reductions. This procedure was carried outin only three cloths because the aim of the present study was to evaluate the efficacy of the disinfection procedures, assuming that hand washing must be done as a previous step of disinfection. After the washing, half of the cloths $(n=35)$ were rinsed with potable water and one piece was boiled in $500 \mathrm{~mL}$ of water for $15 \mathrm{~min}$. The time counting was started immediately after the water started to boil. The other half of the cloths $(n=35)$ were soaked in a 200ppm sodium hypochlorite solution $(10 \mathrm{~mL}$ 
of Q-Boa, 2,5\% active chlorine, diluted in 1 liter of potable water) for $15 \mathrm{~min}$, followed by rinsing with potable water. The concentration of free chlorine of the solutions used in the experiments was determined with a chlorine test kit (CHEMetrices, Inc., Calverton, VA). After disinfection, the cloths were placed into $250 \mathrm{~mL}$ of $0.1 \%$ peptone water and agitated vigorously. A volume of $20 \mu \mathrm{L}$ of the homogenate was directly inoculated on Petri dishes containing PCA, BP and VRBA for the enumeration of TAC, presumptive $S$. aureus and coliforms, respectively. All the counts were performed in duplicates, after incubation at $30{ }^{\circ} \mathrm{C}$, for $24-48 \mathrm{~h}$. Results were expressed as $\log \pm \mathrm{SD}$ $\mathrm{cfu} / \mathrm{cm}^{2}$ of cloth.

\section{Statistical analysis}

Counts were performed in duplicates and submitted to variance analysis (ANOVA) in Microsoft Excel (Microsoft Corp. Redmond, WA). Differences were considered significant when $\mathrm{p}<0.05$.

\section{Results}

The number of bacteria in cleaning cloths was highly variable, however an expressive contamination was observed in all samples. The number of TAC varied from $4.3 \mathrm{log} \mathrm{cfu} / \mathrm{cm}^{2}$ to $8.0 \log \mathrm{cfu} / \mathrm{cm}^{2}$, with a mean of $7.03 \pm$ $6.73 \log \mathrm{cfu} / \mathrm{cm}^{2}$. The majority, i.e., $46 \%$ of the cleaning cloths presented counts of $6.0 \log \mathrm{cfu} / \mathrm{cm}^{2}$, followed by samples with $5.0 \log \mathrm{cfu} / \mathrm{cm}^{2}(28 \%)$ and $7.0 \log \mathrm{cfu} / \mathrm{cm}^{2}$ $(20 \%)$. As expected, all samples showed expressive microbiological contamination and it was not possible to correlate the bacterial counts with the number of daily meals prepared by the food services. Figure 1A demonstrates the frequencies of TAC on the cleaning cloths sampled.

The presumptive coliform number on the cleaning cloths varied from 2.6 to $7.2 \log \mathrm{cfu} / \mathrm{cm}^{2}$ per cloth, and $40 \%$ of the samples presented counts around $6.0 \log \mathrm{cfu} / \mathrm{cm}^{2}$, $31 \%$ presents $5.0 \log \mathrm{cfu} / \mathrm{cm}^{2}$, and $9 \%$ demonstrated $4.0 \log \mathrm{cfu} / \mathrm{cm}^{2}$ (Figure 1B) The mean contamination was $6.21 \pm 5.69 \mathrm{log} \mathrm{cfu} / \mathrm{cm}^{2}$ and in $14 \%$ of the cloths presumptive coliforms were not detected.

Contaminations with presumptive $S$. aureus ranged from $4.0 \log \mathrm{cfu} / \mathrm{cm}^{2}$ up to $6.4 \log \mathrm{cfu} / \mathrm{cm}^{2}$, with mean numbers of $5.55 \pm 4.96 \log \mathrm{cfu} / \mathrm{cm}^{2}$. Among the cleaning cloths tested, $23 \%$ were contaminated with approximately $4.0 \log \mathrm{cfu} / \mathrm{cm}^{2}$ of presumptive $S$. aureus. The same percentage $(23 \%)$ of cloths demonstrated counts of $5.0 \log \mathrm{cfu} / \mathrm{cm}^{2}$. Two cloths $(6 \%)$ presented counts of $6.0 \log \mathrm{cfu} / \mathrm{cm}^{2}$. Presumptive S. aureus was not detected in $48 \%$ of the cloths tested. Frequencies of presumptive $S$. aureus found in the cleaning cloths are demonstrated in Figure 1C.

In general, it was not possible to identify a clear correlation among TAC, presumptive coliforms and presumptive $S$. aureus counts. Some cloths presenting high counts
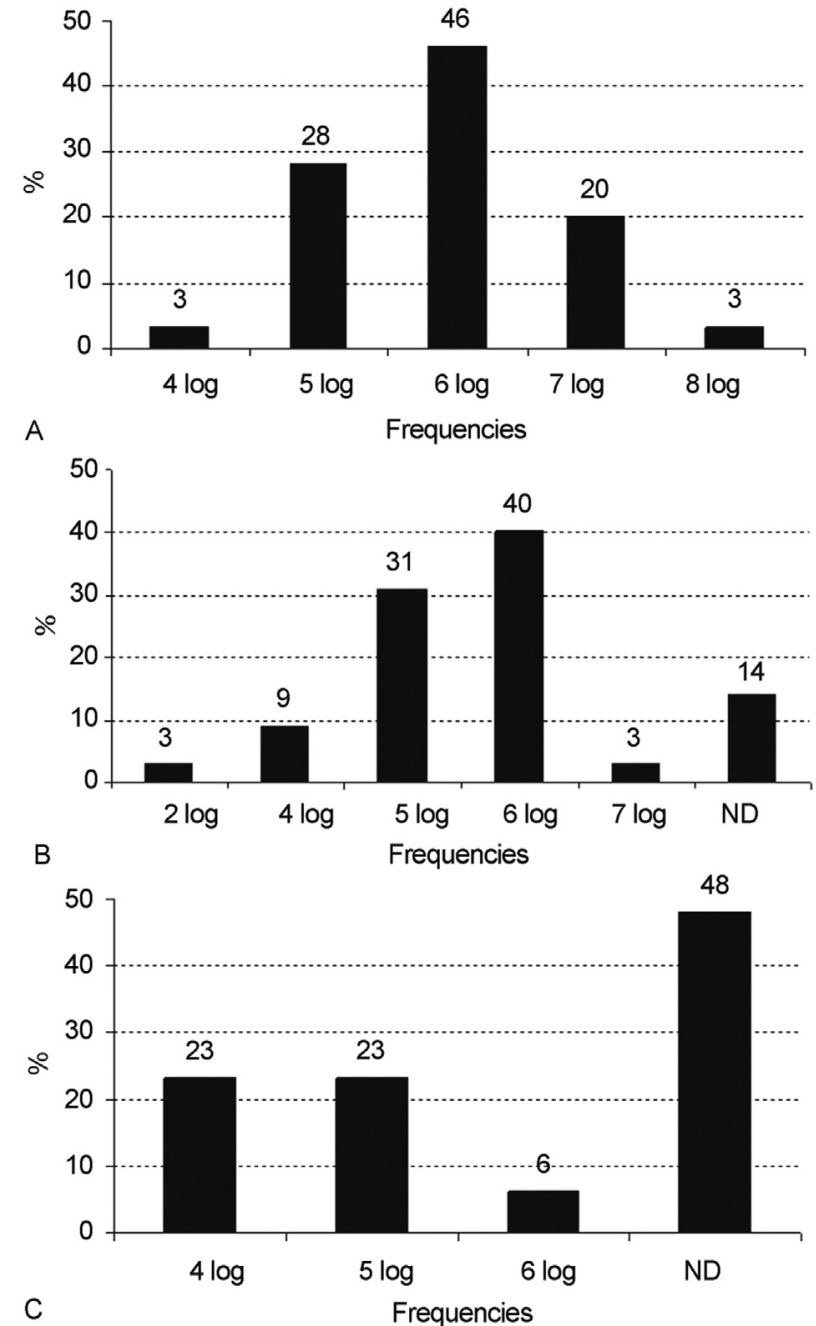

Figure 1 - Frequencies of Total Aerobic Counts (A), presumptive coliform counts (B) and presumptive Staphylococcus aureus counts (C) in cleaning cloths collected in food services of Southern Brazil.

of TAC did not demonstrated presumptive coliforms and/or presumptive S. aureus.

After hand washing and disinfection by both methods, the mean counts of all the microorganisms evaluated decreased significantly $(\mathrm{p}<0.05)$. Considering the mean numbers of TAC observed in the cloths before disinfection, the majority of the samples presented approximately $5.0 \log \mathrm{cfu} / \mathrm{cm}^{2}$ reduction. Hand washing carried out before disinfection contributed with approximately $1.0 \mathrm{log} / \mathrm{cm}^{2}$ reduction.

The cloths boiled in water for 15 min demonstrated TAC counts varying from not detected $\left(<1 \log \mathrm{cfu} / \mathrm{cm}^{2}\right)$ to $3.3 \log \mathrm{cfu} / \mathrm{cm}^{2}$. Among all boiled samples tested for TAC, $48 \%$ presented counts around $1.0 \mathrm{log} \mathrm{cfu} / \mathrm{cm}^{2}, 29 \%$ presented counts of approximately $2.0 \mathrm{log} \mathrm{cfu} / \mathrm{cm}^{2}$ and in $20 \%$ of the samples microorganisms were not detected. Only two boiled cloths $(6 \%)$ demonstrated presumptive coliforms (counts around $1.0 \log \mathrm{cfu} / \mathrm{cm}^{2}$ ) and in the major- 
ity of the cloths (94\%) these microorganisms were not detected. Counts of presumptive $S$. aureus varied from not detected to $1.8 \log \mathrm{cfu} / \mathrm{cm}^{2}$, and in $89 \%$ of the samples presumptive $S$. aureus were not detected.

Cloths washed and disinfected by $200 \mathrm{ppm}$ sodium hypochlorite solution for 15 min demonstrated TAC counts varying from not detected to $3.0 \mathrm{log} \mathrm{cfu} / \mathrm{cm}^{2}$. Only two samples $(6 \%)$ presented counts with approximately $3.0 \mathrm{log} \mathrm{cfu} / \mathrm{cm}^{2}$, eight samples (23\%) presented counts around $2.0 \log \mathrm{cfu} / \mathrm{cm}^{2}$ and 21 samples $(60 \%)$ demonstrated counts around $1.0 \mathrm{log} \mathrm{cfu} / \mathrm{cm}^{2}$. Microorganisms were not detected in five samples (14\%).

After 200 ppm sodium hypochlorite disinfection, the remaining populations of presumptive coliforms varied from not detected up to $3.0 \mathrm{log} \mathrm{cfu} / \mathrm{cm}^{2}$. Two samples presented counts around $3.0 \log \mathrm{cfu} / \mathrm{cm}^{2}$, one sample (3\%) presented counts of $2.0 \log \mathrm{cfu} / \mathrm{cm}^{2}$, four samples $(11 \%)$ presented counts around $1.0 \log \mathrm{cfu} / \mathrm{cm}^{2}$ and in 27 samples (77\%) presumptive coliforms were not detected. Concerning presumptive $S$. aureus, populations varied from not detected to $2.1 \log \mathrm{cfu} / \mathrm{cm}^{2}$, two samples $(6 \%)$ demonstrated counts around $2.0 \log \mathrm{cfu} / \mathrm{cm}^{2}$, six samples (17\%) presented counts around $1.0 \mathrm{log} \mathrm{cfu} / \mathrm{cm}^{2}$ and in 27 samples (77\%) these microorganisms were not detected. Comparing the results of the two disinfection methods, boiling was able to eliminate viable microorganisms in a higher number of samples.

\section{Discussion}

Cleaning cloths are widely used in food services in many countries, including Brazil. Reusable cleaning cloths are frequently found in food services, being used to wipe surfaces, remove food and detergent residues and other cleaning procedures. It is known that during their use cleaning cloths can become heavily contaminated and therefore are considered an important potential source of cross-contamination (Mackintosh and Hoffman, 1984; Tebbut, 1986; Scott and Bloomfield, 1990b; Bloomfield and Scott, 1997; Scott, 1999).

Cleaning cloths presenting high levels of microbial contamination have been reported by several authors. Typically, the contamination levels reported varied from 2.0 to $6.0 \log \mathrm{cfu} / \mathrm{cm}^{2}$ (Davis et al., 1968; Scott and Bloomfield, 1990a, 1990b). The results found in our study demonstrated TAC varying from 4 up to $8 \log \mathrm{cfu} / \mathrm{cm}^{2}$ of cloth. Considering the mean contamination $\left(7.03 \pm 6.73 \log \mathrm{cfu} / \mathrm{cm}^{2}\right)$ and the cloth area $(70 \times 35 \mathrm{~cm})$, a common cloth with a homogeneous distribution of bacteria could contain approximately $9.3 \log$ cfu.

The wide range of counts demonstrated in our study could be explained by the different ways of use of cleaning cloths in food services. At sampling, it was not investigated how long the cloths were in use and if they were sanitized before or during the use. Additionally to the diversity of uses of cleaning cloths, high contamination numbers commonly found in cleaning cloths can be explained by their cotton fiber structure and the frequent presence of organic matter, which may promote microbial attachment and protection (Kusumaningrum et al., 2003). However, it is important to point out that in the present study we considered that the distribution of bacteria in cleaning cloths was homogeneous and the piece of cloth investigated was representative of the entire cloth.

Coliforms have been adopted as food safety and hygiene indicator for many foods (Jay et al., 2005). As previously described (Gerba et al., 2001) coliforms and other microorganisms can be used as indicators of microbial hazard in quantitative microbial risk assessment. Our study recorded mean numbers of presumptive coliforms on cloths of $6.4 \log \mathrm{cfu} / \mathrm{cm}^{2}$, and only in five samples they were not detected. The presumptive coliform contamination of cleaning cloths may be attributed to several factors as: improper handling during food preparation, contamination by raw materials, absence of disinfection procedures, cross-contamination by food handlers, conservation under room temperature and high humidity.

The contamination level of presumptive $S$. aureus observed in this study was distributed across a relative wide range of values, since in several samples these microorganisms were not detected (48\%), while in others the counts reached $6 \log \mathrm{cfu} / \mathrm{cm}^{2}$. As well known, S. aureus is a widespread opportunistic pathogen that can cause food-borne illnesses (Parnes, 1997) and is a common inhabitant of human nose, throat and skin (Arbuthnott, 1990). This pathogen can produce heat-stable toxins responsible for causing food poisoning (Hein et al., 2005). Improper manipulation by personnel was described as being the principal factor for the presence of S. aureus in foods (Hatakka et al., 2000). As previously reported (Kusumaningrum et al., 2003), S. aureus can survive in surfaces over four days and can be easily transferred to food by cross-contamination. As a mesophilic microorganism, the room temperature found in food service kitchens can provide an adequate environment for the multiplication and toxin production. Our results reported mean counts of presumptive S. aureus of $5.6 \mathrm{log}$ $\mathrm{cfu} / \mathrm{cm}^{2}$, which may indicate poor personal hygiene practices and a potential risk of cross-contamination by cleaning cloths. On the other hand, $48 \%$ of the cloths did not presented presumptive $S$. aureus, and this interesting result indicates that such microorganism may not be present in cleaning cloths, even though they are mostly in direct contact with food handlers hands.

In the present study, the number of bacteria was significantly $(\mathrm{p}<0.05)$ reduced in contaminated cleaning cloths by both methods recommended by Portaria 78/2009, i.e. boiling in potable water for 15 min or soaking in 200ppm solution of sodium hypochlorite for $15 \mathrm{~min}$. It is well known that cleaning process is one important step to reduce contamination from surfaces due the mechanical re- 
moval of dirt, soil and microorganisms (Kusumaningrum et al., 2003), however cleaning alone is not sufficient to prevent the presence of pathogenic microorganisms and cross-contamination. By hand washing, the microbial count reductions observed in our study were of approximately $1.0 \mathrm{log}$, demonstrating the need of disinfection methods. One limitation in the present study is that only three cleaning cloths were analyzed after hand washing as an illustrative information because the aim of the study was to compare the two recommended disinfection methods and both should be carried out after hand washing. Together, washing and disinfection procedures were able to reduce around $5 \operatorname{logs}$ of microorganisms, demonstrating that these two easy to perform and not expensive methods are effective.

The disinfection of cleaning cloths appears to play an important role in decontamination process, since microorganisms can be removed from them resulting in microbial inactivation. As found by several authors, adhered bacteria appear to be less sensitive to cleaning and disinfection products than bacteria in suspension (Frank and Koffi, 1990; Briandet et al., 1999; Stopforth et al., 2002).

Sodium hypochlorite has an important biocidal activity and is widely recommended worldwide for the disinfection process, however its biocidal activity depends on several factors such as chlorine concentration, $\mathrm{pH}$, temperature and the presence and quantity of organic matter (Kusumaningrum et al., 2003), besides the time of exposure to the solution. Vegetative bacteria are susceptible to chlorine concentrations of 2 to $500 \mathrm{ppm}$ in environments with low organic matter (Bessems, 1998). In a study conducted in household environments (Rusin et al., 1998), it was demonstrated that disinfection using hypochlorite products in combination with regular cleaning could significantly reduce bacterial contamination of cleaning cloths. However, the use of $4000 \mathrm{ppm}$ hypochlorite solution was not sufficiently effective to reduce contamination of cleaning cloths when they were heavily contaminated (Scot and Bloomfield. 1990b).

In our study, the slightly better reduction levels demonstrated by the boiling method may be partially explained by the better capacity of removing organic matter of this procedure. The high temperature and agitation of the cloths during boiling could facilitate organic matter removal and consequently the microbial inactivation. Boiling in water was also described as an efficient procedure for reduce contamination in cleaning cloths elsewhere (Parnes, 1997; Ikawa and Rossen, 1999; Anonymous, 2000).

Based on the results of the present study, cleaning cloths used in food services of Southern Brazil were highly contaminated, however the disinfection procedures recommended by the regulation 78/2009 (RIO GRANDE DO SUL, 2009) were able to significantly reduce their microbial contamination.

\section{References}

Anonymous (2000) Hygiene prive-huishouding. Voedingscenrum, Research Int., The Hague. The Netherlands.

Arbuthnott JP (1990) Staphylococcal toxins in human disease. J Appl Bacteriol 19:101-107.

Bean NH, Goulding JS, Lao C, Angulo FJ (1996) Surveillance for food-borne disease outbreaks - United States, 1988-1992. MMWR Surveillance Summary 45:1-55.

Bessems E (1998) The effect of practical conditions on the efficacy of disinfectants. Int Biodeterior Biodegrad 41:177-183.

Bloomfield SF, Scott EA (1997) Cross-contamination and infection in the domestic environment and the role of chemical disinfectants. J Appl Microbiol 83:1-9.

Brackett RE, Ho YY, Doyle MP (1994) Ineffectiveness of hot acid sprays to decontaminate Escherichia coli O157:H7 on beef. J Food Prot 57:198-203.

BRASIL. Resolução - RDC n. 216, de 15 de setembro de 2004 da Agência Nacional de Vigilância Sanitária (ANVISA). Dispõe sobre Regulamento Técnico de Boas Práticas para Serviços de Alimentação. Diário Oficial da União, DF, 16 set. 2004.

Briandet R, Leriche V, Carpentier B, Bellon-Fontaine MN (1999) Effects of the growth procedure on the surface hydrophobicity of Listeria monocytogenes cells and their adhesion to stainless steel. J Food Prot 62:994-998.

Cogan TA, Bloomfield SF, Humphrey TJ (1999) The effectiveness of hygiene procedures for prevention of cross-contamination from chicken carcasses in the domestic kitchen. Letters Appl Microbiol 29:354-358.

Davis JG, Blake JR, Woodall CM (1968) A survey of hygienic condition of domestic dish-cloths and tea-towels. Med Off 120:29-32.

De Boer E, Hahne M (1990) Cross contamination with Campylobacter jejuni and Samonella spp. from raw chicken products during food preparation. J Food Prot 53:10671068.

De Wit JC, Brockhuizen G, Kampelmacher EH (1979) Crosscontamination during the preparation of frozen chickens in the kitchen. J Hyg 83:27-32.

Food and Drug Administration (FDA) (1992) Bacteriological Analyses Manual - BAM, $7^{\mathrm{a}}$ ed, pp 51-69.

Frank JF, Koffi. RA (1990) Surface adherent growth of Listeria monocytogenes in associated with increased resistance to surfactant sanitizers and heat. J Food Prot 53:550-554.

Gerba C, Watson S, Kennedy D (2001) Cross-contamination and survival of enteric pathogens in laundry. Hyg Health (no page numbers).

Greig JD, Ravel (2009) A. Analysis of foodborne outbreaks data reported internationally for source attribution. Int J Food Microbiol 130:77-87.

Hassan AN, Frank JF (2004) Attachment of Escherichia coli 0157:H7 grown in tryptic soy broth and nutrient broth to apple and lettuce surfaces as related to cell hydrophobicity, surface charge, and capsule production. Int J Food Microbiol 96:103-109.

Hatakka KJ, Björkhroth HJ, Korkeala KA, Mäki-Petäys (2000) Genotypes and enterotoxicity of Staphylococcus aureus isolated from the hands and nasal cavities of flight-catering employees. J Food Prot 63:1487-1491. 
Hein I, Jorgensen J, Loncarevic S, Wagner M (2005) Quantification of Staphylococcus aureus in unpasteurized bovine and caprine milk by real-time PCR. Res Microbiol 156:554-563.

Ikawa JY, Rossen JS (1999) Reducing bacteria in household sponges. Environ Health 7:18-22.

Jackson V, Blair IS, McDowell DA, Kennedy J, Bolton DJ (2007) The incidence of significant foodborne pathogens in domestic refrigerators. J Food Contr 18:346-351.

Jay JM, Loessner MJ, Golden DA (2005) Modern Food Microbiology. Food Science Text Series, Springer, New York.

Kusumaningrum HD, Riboldi G, Hazelger WC, Beumer RR (2003) Survival of foodborne pathogens on stainless steel surfaces and cross-contamination to foods. Int $\mathrm{J}$ Food Microbiol 85:227-236.

Mackintosh CA, Hoffman PN (1984) An extended model for transfer of microorganisms via the hands. J Hyg 92:345-355.

Norrung B, Buncic S (2008) Microbial safety of meat in the European Union. Meat Sci 78:14-24.

Oliveira FADE, Frazzon AP, Brandelli A, Tondo EC (2007) Use of PCR-Ribotyping, RAPD, and antimicrobial resistance for typing of Salmonella Enteritidis involved in foodborne outbreaks in Southern Brazil. J Infec Developing Countries 1:170-176.

Olsen SJ, MacKinon JS, Goulding JS, Bean NH, Slutsker L (2000) Surveillance for food-borne disease outbreaks United States, 1993-1997. MMRW Surveillance Summary 49:1-51.

Oulahal N, Brice W, Martial A, Degraeve P (2008) Quantitative analyses of survival of Staphylococcus aureus or Listeria innocua on two types of surfaces: polypropylene and stainless steel in contact with three different dairy products. J Food Contr 19:178-185.

Parnes C (1997) Efficacy of sodium hypochlorite bleach and "alternative" products in preventing transfer of bacteria to and from inanimate surfaces. Environ Health 59:14-20.

RIO GRANDE DO SUL. Secretaria da Saúde. Portaria 78 de 30 de janeiro de 2009. Estabelece procedimentos de boas práti- cas para serviços de alimentação, a fim de garantir as condições higiênico-sanitárias do alimento preparado.

Rusin P, Orosz-Coughlin P, Gerba C (1998) Reduction of fecal coliform, coliform and heterotrhphic plate counts bacteria in the household kitchen and bathroom by disinfection with hypochlorite cleaners. J Appl Microbiol 85:819-828.

Scott E (1999) Hygiene issues in the home. Am J Infect Control 27:S4-S21.

Scott E (1997) Food-borne disease and other hygiene issues in the home. J Appl Bacteriol 80:5-9.

Scott E, Bloomfield SF (1990) The survival and transfer of microbial contamination via cloths, hands and utensils. J Appl Bacteriol 68:271-278.

Scott E, Bloomfield SF (1990) Investigation of the effectiveness of detergent washing, drying and chemical disinfection on contamination of cleaning cloths. J Appl Bacteriol 68:279283.

Silva N, Junqueira VCA, Silveira NFA (1997) Manual de métodos de análise microbiológica de alimentos. Varela, São Paulo, 295 pp.

Simone E, Goosen M, Notermans SHW, Borgdorff MW (1997) Investigation of food-borne disease by Food Inspection Services in The Netherlands, 1999 to 1994. J Food Prot 60:442-446.

Sofos JN (2008) Challenges to meat safety in the 21st century. Meat Sci 78:3-13.

Stopforth JD, Samelis MW, Sofos JN, Kendall PA, Smith GC (2002) Biofilm formation by acid-adapted and non-adapted Listeria monocytogenes in fresh beef decontamination washings and its subsequent inactivation with sanitizers. J Food Prot 65:1717-1727.

Tebbut GM (1986) An evaluation of various working practices in shops selling raw and cooked meats. J Hyg 97:81-90.

Walker E, Pritchard C, Forsythe C (2003) Hazard analysis critical control point and prerequisite implementation in small and medium size food business. Food Contr 14:169-174.

All the content of the journal, except where otherwise noted, is licensed under a Creative Commons License CC BY-NC. 